\title{
KOEFISIEN RESTITUSI: MAKNA FISIS, FORMULA MATEMATIS, DAN REDUKSI DIDAKTIS
}

\author{
Dindin Nasrudin', Chaerul Rochman', dan Herni Yuniarti Suhendi' \\ 1. Program Studi Pendidikan Fisika, Jurusan Pendidikan Matematika dan Ilmu \\ Pengetahuan Alam, Fakultas Tarbiyah dan Keguruan Universitas Islam Negeri Sunan \\ Gunung Djati Bandung, Indonesia
}

Email: dindin.nasrudin@uinsgd.ac.id

\begin{abstract}
ABSTRAK
Salah satu materi fisika yang dianggap sulit oleh siswa SMA adalah konsep tumbukan yang di dalamnya membahas koefisien restitusi (e). Atas dasar itu, koefisien restitusi menjadi salah satu kajian yang dibahas pada mata kuliah Pendalaman Fisika II bagi calon guru fisika di salah satu LPTK di Jawa Barat. Makalah ini menggambarkan profil calon guru fisika dalam memahami makna fisis dari koefisien restitusi, cara menuliskan formula matematis dan pemilihan reduksi didaktis yang tepat dalam membelajarkan konsep koefisien restitusi pada siswa SMA. Populasi penelitian ini adalah calon guru fisika pada salah satu LPTK di Jawa Barat, sedangkan sampelnya adalah 80 calon guru fisika yang sudah mengambil mata kuliah Pendalaman Fisika SL II. Dengan menggunakan metode crosssectional survey, diperoleh informasi bahwa (1) Jumlah responden yang menjawab makna fisis dari koefisien restitusi dalam kategori tepat sebanyak: 39,7 \%, kategori kurang tepat sebanyak $22 \%$ dan sisanya kategori tidak tepat sebanyak 38,3\%. (2) Formula matematis dari koefisien restitusi yang dipilih responden adalah $91.3 \%$ menggunakan TIPE B1, $2.8 \%$ menggunakan TIPE B2 dan sisanya $5.7 \%$ menggunakan TIPE B4. (3) Reduksi didaktis yang dipilih oleh responden dalam membelajarkan konsep koefisien restitusi pada siswa SMA adalah 10.2 \% dengan cara kembali ke makna kualitatif, 66.7\% dengan menggunakan gambar dan sketsa, 20.3\% menggunakan analogi, sementara sisanya menggunakan partikularisasi (1.4\%) dan generalisasi (1.4\%)
\end{abstract}

Kata kunci: Koefisien restitusi, Makna fisis, formula matematis, Reduksi didaktis

\begin{abstract}
One of the physics matter that is considered difficult by high school students is the concept of collision in which discuss the coefficient of restitution (e). On that basis, the restitution coefficient becomes one of the studies discussed in Physics Depth II for pre-service physics teacher in one of LPTK in West Java. This paper describes the profile of preservice physics teacher in understanding the physical meanings of restitution coefficients, how to write mathematical formulas and the appropriate didactic reduction in learning the concept of restitution coefficients in high school students. The population of this research is pre-service physics teacher in one of LPTK in West Java, while the sample is 80 pre-service physics teacher who has taken the subject of Physics Depth II. By using cross-sectional survey method, it was found that (1) the number of respondents who answered the physical meaning of the restitution coefficient in the right category were: $39.7 \%$, the less appropriate category was $22 \%$ and the rest of the category was not exactly 38.3\%. (2) The mathematical formula of the selected restitution coefficient is $91.3 \%$ using TYPE B1, 2.8\% using TYPE $B 2$ and the remaining 5.7\% using TYPE B4. (3) The didactic reduction chosen by the respondents in learning the concept of restitution coefficient in high school students is $10.2 \%$ by returning to the qualitative mean, $66.7 \%$ using drawings and sketches, 20.3\% using analogy, while the rest using particularization (1.4\%) and generalization (1.4\%).
\end{abstract}

Keywords: The coefficient of restitution, physical meaning, mathematical formulas, Didactic reduction 


\section{PENDAHULUAN}

Mata kuliah Pendalaman Fisika Sekolah Lanjutan II (SL II) adalah mata kuliah yang ditujukan untuk memberikan kemampuan dan pemahaman kepada mahasiswa calon guru fisika tentang konsep-konsep essensial terpilih dan aktual dari materi-materi bahan ajar sekolah tingkat SMA yang dianggap sulit oleh peserta didik dan topiktopik yang tingkat kesulitannya tinggi berdasarkan kurikulum yang berlaku. Melalui mata kuliah ini, calon guru diharapkan dapat menambah wawasan tentang metode dan strategi yang tepat untuk membelajarkan fisika pada peserta didik serta memiliki sikap inovatif terhadap penyelesaian masalah pembelajaran di sekolah setingkat SMA (Dirgantara dan Nasrudin, 2016). Salah satu materi yang dibahas pada mata kuliah Pendalaman Fisika SL II ini adalah konsep Momentum dan Impuls yang di dalamnya membahas koefisien restitusi pada kasus tumbukan.

Kompetensi Dasar (KD) yang terkait dengan materi momentum dan impuls terdapat dalam KD 3.10 yakni menerapkan konsep momentum dan impuls, serta hukum kekekalan momentum dalam kehidupan sehari-hari serta KD 4.10 yakni menyajikan hasil pengujian penerapan hukum kekekalan momentum, misalnya bola jatuh bebas ke lantai dan roket sederhana (Permendikbud Nomor 24 Tahun 2016). KD merupakan kemampuan dan materi pembelajaran minimal yang harus dicapai peserta didik untuk suatu mata pelajaran pada masing-masing satuan pendidikan yang mengacu pada kompetensi inti. (Permendikbud RI Nomor 24 Tahun 2016). KD merupakan acuan bagi guru dalam menyusun silabus, membuat Rancangan Pelaksanaan Pembelajaran (RPP), melaksanakan pembelajaran dan mengevaluasi proses dan hasil pembelajaran. Selain sebagai kemampuan minimal yang harus dicapai oleh siswa, KD juga sekaligus sebagai target minimal yang harus dicapai oleh guru dalam membelajarkan peserta didik. Seorang guru yang professional akan berusaha membuat RPP yang terbaik, bahan ajar yang terbaik, pendekatan, model, metode dan strategi terbaik, instrumen evaluasi terbaik agar peserta didiknya sampai pada KD yang diharapkan.

Beberapa penelitian terkait lemahnya peserta didik dalam memahami konsep Momentum dan Impuls telah banyak dilakukan. Salah satunya penelitian Rufaida (Rufaida, 1998). Hasil penelitian yang diperoleh Rufaida: Jenis kesalahan yang dilakukan siswa dalam menyelesaikan soal-soal pada materi pokok Momentum dan Impuls adalah (i) kesalahan strategi, (ii) kesalahan terjemahan, (iii) kesalahan konsep, (iv) kesalahan hitung, dan (v) kesalahan tanda (matematis). Salah satu materi pada pokok bahasan Momentum dan Impuls yang dianggap sulit dan banyaknya kesalahan yang dilakukan oleh peserta didik adalah penerapan koefisien restitusi dalam menyelesaikan berbagai soal terkait tumbukan. Hal inilah yang menjadi pendorong bagi peneliti untuk mengetahui sejauh mana pengetahuan calon guru fisika dalam memahami arti fisis koefisien restitusi, penulisan formula matematis dan pemilihan reduksi didaktis dalam membelajarkan konsep koefisien restitusi pada peserta didik.

Pengertian koefisien restitusi diberikan oleh Tipler (1991) sebagai ukuran keelastisan sebuah tumbukan atau rasio antara kelajuan saling menjauh relatif dan kelajuan saling mendekat relative (Tipler, 1998). Definisi lain dikemukakan oleh Buche dan Hecht (2006), koefisien restitusi merupakan bilangan murni yang diberikan oleh

$$
e=\frac{v_{2 x}-v_{1 x}}{u_{1 x}-u_{2 x}}
$$


dengan $\left|u_{1 x}-u_{2 x}\right|$ adalah laju relatif sebelum tumbukan dan $\left|v_{2 x}-v_{1 x}\right|$ adalah laju relatif setelah tumbukan (Bueche, 2006). Kanginan (2013:227) mendeninisikan koefisien restitusi (e) sebagai negatif perbandingan antara kecepatan relatif sesaat sesudah tumbukan dengan kecepatan relatif sebelum tumbukan, untuk tumbukan satu dimensi (Kanginan, 2013). Selanjutnya, Kanginan memformulasikan koefisien restitusi sebagai:

$$
e=\frac{-\Delta v^{\prime}}{\Delta v} \text { sehingga } e=\frac{-\left(v_{2}{ }^{\prime}-v_{1}{ }^{\prime}\right)}{v_{2}-v_{1}}
$$

Definisi serupa dikemukan oleh Setiawan (2005:151). Hanya saja penulisan formula matematisnya agak berbeda seperti terlihat pada pers. 3 berikut.

$$
e=-\left(\frac{v_{1}{ }^{\prime}-v_{2}{ }^{\prime}}{v_{1}-v_{2}}\right)
$$

Penulisan pers.2 di atas kami sebut sebagai pers. TIPE A yakni cara penulisan laju relatif mendahulukan $v_{1}$ dibanding $v_{2}$. Sementara penulisan sebaliknya (pers.3), kami menyebutnya pers. TIPE B. Selain tokoh di atas, penulisan formula matematis untuk koefiisen restitusi yang mengikuti tipe A antara lain: Palupi dkk (2009:139). Abdullah (2016:451), Cari (2009:178), Dudung (2008:5) dan Sarwono dkk (2009:105). Sementara itu, penulisan untuk tipe B diikuiti oleh Indrajit (2009:97), Wulandari (2012:102). Saripudin, Aip dkk (2009), Siswanto dkk (2009:106), Handayani \& Damari (2009:78) Supiyanto (2006:122) dan Haryadi (2009:93). Akhirnya, berbagai cara penulisan formula matematis untuk koefisien restitusi diberikan pada tabel 1 .

Tabel 1. Penulisan Formula Matematis untuk

\begin{tabular}{|c|c|c|}
\hline NO. & TIPE A & TIPE B \\
\hline 1 & $\begin{array}{c}e=\frac{\left|v_{2}{ }^{\prime}-v_{1}{ }^{\prime}\right|}{\left|v_{2}-v_{1}\right|} \\
\text { Adaftasi dari } \\
\text { Buche dan Hecht } \\
\quad \text { (2006) }\end{array}$ & $\begin{array}{c}e=-\left(\frac{v_{1}{ }^{\prime}-v_{2}{ }^{\prime}}{v_{1}-v_{2}}\right) \\
\text { Setiawan (2005:151), } \\
\text { Indrajit (2009:97)[ }\end{array}$ \\
\hline 2 & $\begin{array}{c}e=\frac{-\left(v_{2}^{\prime}-v_{1}^{\prime}\right)}{v_{2}-v_{1}} \\
\text { Kanginan } \\
(2013: 227)\end{array}$ & $\begin{array}{c}e=\frac{-\left(v_{1}{ }^{\prime}-v_{2}{ }^{\prime}\right)}{v_{1}-v_{2}} \\
\text { Wulandari (2012:102). }\end{array}$ \\
\hline 3 & $\begin{array}{c}e=\frac{\left(v_{2}^{\prime}-v_{1}^{\prime}\right)}{\left(v_{2}-v_{1}\right)} \\
\text { Palupi dkk } \\
(2009: 139) .\end{array}$ & $\begin{array}{c}e=-\frac{\left(v_{1}{ }^{\prime}-v_{2}{ }^{\prime}\right)}{\left(v_{1}-v_{2}\right)} \\
\text { Saripudin dkk } \\
\text { (2009:94),Siswanto } \\
\text { dkk (2009:106) }\end{array}$ \\
\hline 4 & $\begin{array}{c}e=-\frac{v_{2}{ }^{\prime}-v_{1}{ }^{\prime}}{v_{2}-v_{1}} \\
\text { Abdullah } \\
(2016: 451), \text { Cari } \\
\text { (2009:178) dan } \\
\text { Dudung (2008:5) }\end{array}$ & $\begin{array}{c}e=-\frac{v_{1}^{\prime}-v_{2}^{\prime}}{v_{1}-v_{2}} \\
\text { Handayani, Sri \& } \\
\text { Damari, Ari. (2009:78) }\end{array}$ \\
\hline 5 & $\begin{array}{c}e=-\frac{\left(v_{2}{ }^{\prime}-v_{1}{ }^{\prime}\right)}{v_{2}-v_{1}} \\
\text { Sarwono dkk } \\
\text { (2009:105). }\end{array}$ & $\begin{array}{c}e=-\frac{\left(v_{1}^{\prime}-v_{2}^{\prime}\right)}{v_{1}-v_{2}} \\
\text { Supiyanto (2006:122), } \\
\text { Haryadi }(2009: 93)\end{array}$ \\
\hline
\end{tabular}
Koefisien Restitusi

\section{METODE PENELITIAN}

Penelitian ini bertujuan ingin mendeskripsikan profil calon guru fisika dalam memahami makna fisis, formula matematis dan pilihan reduksi didaktis dari koefisien restitusi. Metode yang digunakan dalam penelitian ini adalah metode Cross-Sectional Survey. Menurut 
Frankel \& Wallen (2009), metode ini digunakan dalam rangka mengumpulkan informasi dari sampel yang digambarkan dari populasi yang sudah ditentukan sebelumnya. Ada tiga karakter dalam penelitian survey ini, yaitu: (1) informasi dikumpulkan dari sekelompok orang untuk menggambarkan beberapa aspek atau karakteristik yang ingin diketahui, (2) Cara utama yang dipilih untuk menjaring data adalah dengan mengajukan pertanyaan. (3) Informasi dikumpulkan dari sampel yang mewakili populasi (Freenkel dan Wallen, 2009).

Dalam dunia pendidikan, Creswell membagi tipe penelitian cross-sectional survey menjadi empat bentuk, yakni (1) memeriksa sikap, keyakinan, pendapat/opini dan parktik tertentu yang berlaku saat ini, (2) membandingkan dua kelompok pendidikan atau lebih dalam kaitan dengan sikap, keyakinan, pendapat dan praktik tertentu (3) mengukur kebutuhan masyarakat akan pelayanan pendidikan yang berkaitan dengan program tertentu, (4) mengevaluasi program dan (5) asesmen skala besar terhadap sebuah kebijakan, Maksud dari penggunaan rancangan cross-sectional survey dalam penelitian ini adalah untuk mengevaluasi program perkuliahan yang sudah dilakukan (tipe 4) (Cresswell, 2015).

Populasi dalam penelitian ini adalah mahasiswa calon guru fisika di salah satu LPTK di Jawa Barat. Sementara sampel penelitiannya 80 mahasiswa yang sudah mengambail mata kuliah Pendalaman Fisika SL II. Untuk mendapatkan profil calon guru dalam memahami makna fisis, penulisan formula matematis dan pemilihan reduksi didaktis adalah dengan cara memberikan soal 3 buah soal uraian (essay) yang memuat ke tiga komponen (data) penelitian yang akan dijaring.

Pemilihan instrumen tes berupa soal uraian dipandang cocok digunakan karena memberikan ruang kepada responden untuk mengeluarkan semua gagasan, ide dan pengetahuan yang selama ini mereka dapat disbanding. Pilihan Ganda (PG). Soal uraian yang dibuat dilengkapi dengan rubrik penilaian. Dalam rangka mempermudah proses pemeriksaan lembar jawaban dan menyesuaikan dengan tujuan dan karakteristik penelitian, peneliti membuat klasifikasi atau kategori jawaban.

Untuk soal no.1 yang menanyakan makna fisis dari koefisien restitusi, peneliti membagi kategori jawaban ke dalam tiga tipe yakni jawaban tepat, jawaban kurang tepat dan jawaban tidak tepat. Kategori jawaban tepat diberikan pada jawaban yang sesuai dengan kunci jawaban yang telah dibuat. Ketepatan jawaban tidak dimaknai kesamaan redaksi melainkan ketepatan makna, substansi dan kata kunci. Kategori jawaban kurang tepat diberikan apabila jawaban yang diberikan masih memuat sedikit atau sebagian dari jawaban yang diberikan walaupun tidak tepat seutuhnya. Sementara jawaban tidak tepat diberikan pada jawaban yang sama sekali melenceng dan tidak ada hubungan sedikit pun dengan kunci jawaban yang sudah disiapkan. Pemilihan metode penilaian kategori jawaban ke dalam tiga tipe ini dilakukan dalam rangka memberikan gambaran kondisi atau profil calon guru dalam memahami makna fisis koefisien restitusi.

Untuk soal no.2 yang menanyakan formula matematis dari koefisien restitusi dilakukan dengan cara memperlihatkan 10 jenis tipe penulisan koefisien restitusi di dalam slide untuk kemudian dipilih oleh responden berdasarkan pengalaman, pengetahuan dan keyakinan responden dengan disertai alasan memilih jawaban tersebut. Soal kedua dimaksudkan untuk mendapatkan respon dari responden dalam hal ini calon guru fisika dalam menuliskan formula matematis dari koefisien restitusi. Sama 
seperti dengan soal no.2, untuk soal no.3, responden diminta untuk menuliskan metode reduksi didaktis seperti apa yang menurut responden dianggap paling cocok dalam membelajarkan koefisien restitusi.

Setelah semua jawaban diperoleh dan diberikan penilaian, langkah selanjutnya adalah mengelompokkan dan membuat persentase tiap kategori jawaban dari para responden. Persentase kategori responden inilah yang diharapkan oleh peneliti untuk mendapatkan gambaran profil calon guru fisika dalam memahami topik koefisien restitusi. Hasil penelitian ini selanjutnya akan dijadikan bahan evaluasi dan intropeksi oleh peneliti untuk memperbaiki perkuliahan yang akan datang dan meningkatkankan kualitas pembelajaran. Adapun pembahasan mengenai profil dari masing-masing kriteria tersebut lebih lengkapnya pada pembahasan berikut ini.

\section{HASIL DAN PEMBAHASAN}

Evaluasi program perkuliahan dipandang perlu dilakukan dalam rangka meningkatkan kualitas pembelajaran. Dalam pendekatan sistem, evalusi perkuliahan dapat dilihat dari mulai input, proses, output, outcome, benefit sampai impact. Input perkuliahan pendalaman Fisika SL II adalah mahasiswa yang mengontrak mata kuliah tersebut dengan segala macam atributnya seperti kemampuan awal mahasiswa, kemampuan Fisika Dasar, wawasan dan pengetahuan tentang pendekatan, model-model, metode dan strategi pembelajaran serta pengetahuan lain terkait fisika dan cara membelajarkannya.

Evaluasi input perkuliahan biasa dilakukan pada saat pertemuan di awal perkuliahan melalui instrumen angket dan pre test serta kontrak perkuliahan. Evaluasi proses perkuliahan biasa dilakukan di sela-sela proses perkuliahan. Dosen dapat meminta tanggapan atau respon terhadap perkuliahan yang telah dilakukan dan meminta masukan untuk proses perkuliahan yang selanjutnya. Sementara itu, penelitian ini dilakukan dalam rangka melakukan evaluasi output perkuliahan pada salah satu sub materi dalam perkuliahan Pendidikan Fisika SL II, yakni pembahasan koefisien restitusi dalam kasus tumbukan.

\section{Profil Pemahaman Calon Guru terhadap Makna Fisis Koefisien Restitusi}

Hasil analisis data terhadap pemahaman calon guru pada makna fisik koefisien restitusi dapat dilihat dalam gambar 1 di bawah ini.

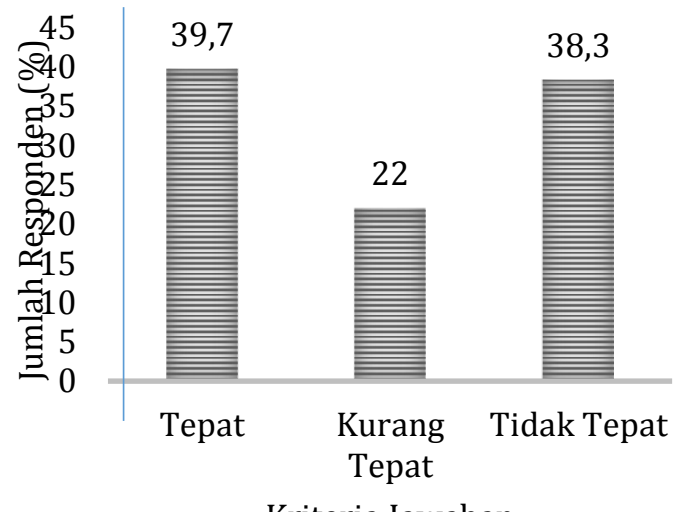

Kriteria Jawaban

Gambar 1. Profil Pemahaman Calon Guru terhadap Makna Fisis Koefisien Restitusi

Berdasarkan gambar 1 di atas, kita dapat melihat bahwa persentase calon guru fisika yang sudah memahami makna fisis dari koefisien restititusi baru sekitar 40 persen. Sementara sisanya masih belum memahaminya. Alasan rendahnya persantese ini tentu banyak dan beragam bila kita tanyakan pada responden, mulai dari lupa, belum baca atau karena belum memahaminya. Akan tetapi semua alasan yang diberikan oleh semua responden menjadi tidak terlalu penting karena sesungguhnya pertanyaan besar bagi peneliti dalam hal ini dosen 
Pendalaman Fisika SL II adalah mengapa masih banyak calon guru yang belum memahami arti fisis dari koefisien restitusi terkait dengan pembelajaran yang telah diberikan oleh dosen. Apakah cara mengajar dosen yang tidak tepat? Apakah pendekatan atau metode yang digunakan belum efektif meningkatkan pemahaman mereka? Jika memang benar bahwa kebanyakan mahasiswa belum memahami konsep yang dimaksud berarti pembelajaran yang diberikan oleh dosen selama ini belum dapat meningkatkan pemahaman mereka. Oleh karena itu, pembelajaran yang selama ini diberikan harus dievaluasi kembali dan diperbaiki.

Fenomena rendahnya persentase calon guru fisika dalam memahami suatu konsep fisika seperti pemahaman koefisien restitusi dirasakan sangat berbahaya berhubung mereka akan mengajarkan konsep tersebut pada siswanya kelak di SMA. Bila yang diajarkan kepada siswa adalah konsep yang salah, maka yang salah itu akan terus berlanjut tanpa henti. Menurunkan persentase calon guru yang belum paham akan makna fisis dari koefisien restitusi menjadi tanggung jawab dosen.

\section{Profil Pemahaman Calon Guru terhadap Formula Matematis Koefisien Restitusi}

Bila kita perhatikan buku-buku Fisika Dasar yang digunakan di S1 seperti Tipler, Giancoli, Halliday \& Resnick, Serway dll sedikit sekali buku yang memberikan persamaan koefiseien restitusi secara langsung dalam sebuah persamaan seperti yang diperlihatkan dalam tabel 1 . Justeru kita akan menemukan formula matematis itu dalam bukubuku SMA. Pada praktik pembelajaran Momentum dan Impuls di SMA, pembelajaran biasanya diawali dengan mengetengahkan konsep momentum, hukum kekekalan momentum dan aplikasi hukum kekekalan momentum yang salah satunya berlaku dalam ketiga jenis tumbukan yakni tumbukan lenting sempurna, tumbukan tidak lenting sama sekali dan tumbukan lenting sebagian, Biasanya, koefisien restitusi muncul pada saat pembahasan tumbukan lenting sebagian. Tidak sedikit guru yang memberikan rumus jadi dari koefisien restitusi tanpa menganalisis awal mula adanya persamaan koefisien restitusi. Adapun respon dari calon guru yang disurvai terkait formula matematis yang dipilih digambarkan dalam gambar 2 .

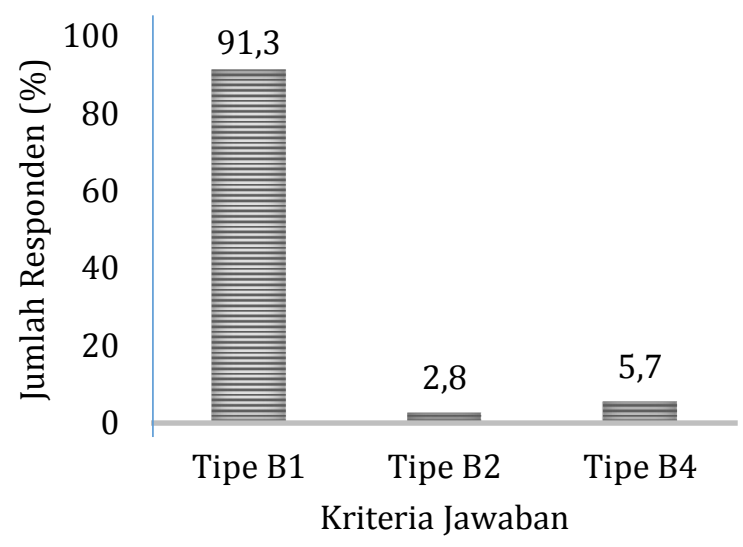

Gambar 2. Profil Pemahaman Calon Guru terhadap Formula Matematis Koefisien Restitusi

Berdasarkan gambar 2 di atas, kita dapat melihat bahwa formula matematis yang dipilih oleh calon guru terpetakan menjadi 3 model persamaan dengan 91.3 persen responden memilih tipe persamaan TIPE B1, seperti yang dipakai oleh Setiawan (2005:151) dan Indrajit (2009:97) yakni persamaan:

$$
e=-\left(\frac{v_{1}{ }^{\prime}-v_{2}{ }^{\prime}}{v_{1}-v_{2}}\right)
$$

Berdasarkan hasil diskusi dan tanya jawab seputar alasan pemilihan tipe B1 yang akan digunakan oleh calon guru dalam mengajar diperoleh informasi bahwa persamaan TIPE B1 dirasa lebih aman bagi siswa dibanding persamaan lain. Dikatakan aman karena siswa tidak akan terkecoh dengan tanda minus dan 
penggunaan tanda kurung pada persamaan koefisien restitusi (e).

\section{Profil Pemilihan Reduksi Didaktis untuk Membelajarkan Koefisien Restitusi pada Peserta Didik}

Istilah reduksi didaktik berasal dari bahasa Jerman "Didaktische Reduktion". Menurut Anwar (1994), istilah ini pertama kali dipopulerkan oleh Gustav Gruner pada tahun1967. Reduksi didaktik berasal dari dua kata yakni reduksi dan didaktik. Istilah reduksi dapat dimaknai sebagai pengurangan atau penurunan, sedangkan didaktik dalam arti sempit diartikan dapat diartikan sebagai ilmu yang terkait dengan pengajaran. Oleh karena itu, Reduksi Didaktik (RD) dapat diartikan sebagai sebuah proses perubahan struktur materi ajar dengan cara mereduksi tingkat kesulitan materi subyek baik dari sisi kualitas maupun kuantitas, sehingga menjadi materi subyek yang lebih mudah dipahami siswa (Herlanti dkk, 2008). Selanjutnya, Anwar memperkenalkan delapan cara mereduksi bahan ajar secara didaktik yakni kembali kepada tahapan kualitatif, pengabaian, penggunaan penjelasan berupa gambar (visual) dan simbol, penggunaan analogi, dan penggunaan tingkat perkembangan sejarah (teknik historis), generalisasi dan partikularisasi.

Ke delapan cara reduksi deduktik ini sudah diberikan pada calon guru fisika sejak perkuliahan Pendalaman Fisika SL I. Mereka dipandang cukup tahu dan paham kapan cara itu digunakan. Terkait dengan konsep pembahasan koefisien restitusi peneliti berkeyakinan bahwa konsep tersebut harus mengalami reduksi didaktis agar mudah diterima dan dipahami oleh siswa. Berdasarkan survai yang dilakukan oleh peneliti terhadap calon guru fisika dalam memilih reduksi didatis dalam membelajarkan konsep koefisien restitusi, diperoleh informasi sebagaimana yang digambarkan pada gambar 3 .

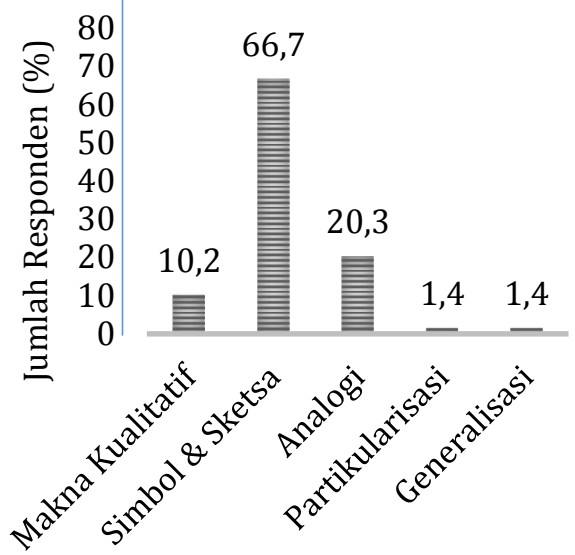

Kriteria Jawaban

Gambar 3. Profil Pemilihan Reduksi Didaktis untuk Membelajarkan Koefisien Restitusi pada Peserta Didik

Berdasarkan Gambar di atas dapat kita lihat bahwa mayoritas calon guru fisika memilih menggunakan simbol dan sketsa dalam membelajarkan konsep koefisien restitusi (66.7 \%). Pemilihan ini dipandang tepat sebab penggunaan sketsa dan simbol sangat bermanfaat untuk menggambarkan proses tumbukan yang terjadi pada benda sehingga menentukan koefisien restitusi dipandang jauh lebih mudah. Selain dengan simbol dan sketsa, penjelasan tentang koefisien restitusi dapat pula menggunakan analogi (20.3\%), hanya saja penggunaan analogi harus hati-hati sebab penngunaan analogi harus sesuai dengan apa yang akan dianalogikan. Cara selanjutnya adalah kembali ke makna kualitatif (10.2\%), cara ini sebenarnya sama dengan kembali ke makna fisis dengan mengabaikan formula matematis

\section{KESIMPULAN}

Berdasarkan hasil analisis data yang telah dilakukan, simpulan yang dapat ditarik adalah (1) 
Calon guru fisika yang sudah mengambil mata kuliah Pendalaman Fisika SL II tidak semuanya memahami makna fisis dari koefisien restitusi. Hal ini dibuktikan dengan jumlah responden yang memberikan jawaban tepat sebanyak: $39.7 \%$, kurang tepat sebanyak $22 \%$ dan sisanya tidak tepat sebanyak 38,3 \%. (2) Pemilihan formula matematis dari koefisien restitusi yang dipilih oleh calon guru fisika adalah TIPE B1 sebanyak $91.3 \%$, TIPE B2 sebanyak $2.8 \%$ dan sisanya 5.7 $\%$ menggunakan TIPE B4. (3) Adapaun reduksi didaktis yang dipilih oleh responden dalam membelajarkan konsep koefisien restitusi pada siswa SMA adalah $10.2 \%$ dengan cara kembali ke makna kualitatif, $66.7 \%$ dengan menggunakan gambar dan sketsa, $20.3 \%$ menggunakan analogi, sementara sisanya menggunakan partikularisasi (1.4\%) dan generalisasi (1.4\%).

\section{UCAPAN TERIMAKASIH}

Penulis mengucapkan terima kasih kepada Bapak Drs. Yudi Dirgantara atas diskusi yang sangat bermanfaat dan pemberian informasi referensi yang relevan dalam penyusunan makalah ini. Penulis juga tidak lupa mengucapkan terima kasih yang sebesar-besarnya pada Saudari Mila Faizatul Millah yang telah membantu proses editing makalah ini.

\section{DAFTAR PUSTAKA}

Abdullah, Mikrajudin. 2016. Fisika Dasar I. Bandung: ITB

Anonim. 2009. Aktif Belajar Fisika untuk SMA \& MA Kelas XI. Jakarta: Pusat Perbukuan Departemen Pendidikan Nasional Bueche, Frederick \& Hect, Eugene. Fisika Universitas Edisi Kesepuluh. Jakarta: Erlangga (2006)
Creswell, Jhon. 2015. Educational Reseach, Planning, Conducting, and Evaluating Quantitative and Qualitative, ed.5. Pearson Education Inc

Dirgantara, Yudi \& Nasrudin, Dindin. 2016. Rancangan Pembelajaran Semester Pendalaman Fisika Sekolah Lanjutan II. UIN Sunan Gunung Djati Bandung

Dudung A.S. 2008. Mengerti Fisika SMA/MA. Bandung: Yrama Widya

Fraenkel, J. R \& Wallen N.E. 2009. "How To Design and Evaluate Reseach in Education Sevent Edition, New York: McGraw-Hill

Handayani, Sri \& Damari, Ari. 2009. Fisika untuk SMA dan MA Kelas XI. Jakarta: Pusat Perbukuan Departemen Pendidikan Nasional.

Haryadi, Bambang. 2009. Fisika untuk SMA/MA Kelas XI. Jakarta: Pusat Perbukuan Departemen Pendidikan Nasional

Herlanti, Yanti dkk. 2008. Strategi Pengolahan Bahan Ajar IPA (Hasil Kajian Terhadap Teori Reduksi Didaktis dan Pedagogi Materi Subyek) Edusains 1(1), Juni 2008 ISSN 19797281. Halaman 26-38

Indrajit, Dudi. 2009. Mudah dan Aktif Belajar Fisika untuk Kelas XI Sekolah Menengah Atas/Madrasah Aliyah Program Ilmu Pengetahuan Alam. Jakarta: Pusat Perbukuan Departemen Pendidikan Nasional

Kanginan, Marthen. 2013. Fisika untuk SMA/MA Kelas XI Kelompok Peminatan Matematika dan Ilmu Alam. Jakarta: Erlangga

Lampiran Permendikbud RI Nomor 24 Tahun 2016 tentang Kompetensi Inti dan Kompetensi Dasar Pelajaran pada Kurikulum 2013 pada Pendidikan Dasar dan Pendidikan Menengah

Palupi, Dwi Satya dkk. 2009. Fisika untuk SMA dan MA Kelas XI. Jakarta: Pusat Perbukuan Departemen Pendidikan Nasional 
Permendikbud RI Nomor 24 Tahun 2016 tentang

Kompetensi Inti dan Kompetensi Dasar

Pelajaran pada Kurikulum 2013 pada

Pendidikan Dasar dan Pendidikan Menengah

Rufaida, SA dkk. Profil Kesalahan Siswa SMA

dalam Pengerjaan Soal pada Materi

Momentum dan Impuls. Pendidikan Fisika FKIP UNS

Saeful Anwar. 1994, Bahan Kuliah Pengolahan Bahan Ajar. Makalah Kuliah Bandung: PPS UPI

Saripudin, Aip dkk. 2009. Fisika untuk Kelas XI Sekolah Menengah Atas/ Madrasah Aliyah Program Ilmu Pengetahuan Alam. Jakarta: Pusat Perbukuan Departemen Pendidikan Nasional

Setiawan, Hilman. Fisika SMA/MA Kelas XI $2 A$. Jakarta: Piranti (2005)

Sarwono dkk. 2009. SMA dan MA Fisika 2 Mudah dan Sederhana. Jakarta: Pusat Perbukuan Departemen Pendidikan Nasional

Siswanto \& Sukaryadi. 2009. Kompetensi Fisika untuk SMA/MA Kelas XI. Jakarta: Pusat Perbukuan Departemen Pendidikan Nasional Supiyanto. 2006. Fisika untuk SMA Kelas XI. Jakarta: Phibeta

Tipler, Paul. 1998. Fisika untuk Sains dan Teknik Jilid 1. Jakarta: Erlangga

Wulandari, Yayan. 2012. 1001 Ulasan Fisika SMA untuk Kelas XI. Tanggerang: Scientific Press 